\title{
The Influence of Interest Rate Liberalization on Commercial Banks and Its Countermeasures
}

\author{
Mengting Jiang* \\ Tongling College, Tongling City, Anhui Province 244000, China. E-mail: 2964123257@qq.com
}

\begin{abstract}
The liberalization of interest rate is an important part of the financial reform in China under the current economic situation, and it is the inevitable result of the economic development of China to a certain extent. With the deepening of interest rate liberalization reform in China, commercial banks have been affected to a certain extent; the deposit and loan spread, which accounts for the main income of commercial banks, has been narrowed, and the profit space of commercial banks has been further reduced. Therefore, this paper discusses the impact of interest rate liberalization on commercial banks and the choices that commercial banks should make under this situation.
\end{abstract}

Keywords: Interest Rate Liberalization; Commercial Banks; Influence; Strategy

\section{Introduction}

The liberalization of interest rate means that the monetary authorities hand over the decision power of interest rate to the market, and the main body of the market determines the interest rate independently, while the monetary authority indirectly affects and determines the level of market interest rate by using monetary policy tools in order to achieve the goal of monetary policy ${ }^{[1]}$. Interest rates are the prices of funds and play a vital role in the economy and society. According to the theory of interest rate put forward by famous scholars McKinnon and Shaw, for developing countries, in order to promote economic development, a free and loose financial environment should be created. Under the influence of their thoughts, China has also embarked on the journey of interest rate liberalization. At the third plenary session of the 14th Central Committee of the CPC in 1993, China put forward the idea of interest rate liberalization for the first time, and began to carry out the reform of interest rate liberalization in 1996. First, the People's Bank of China liberalized the inter-bank lending market interest rate, and then liberalized the inter-bank bond repurchase, market policy-oriented financial bonds and bond issuance interest rates one after another. In 2013, the loan interest rate was fully liberalized, and in 2015 the People's Bank of China decided to eliminate the upper limit of floating deposit rate of commercial banks, marking the preliminary end of the reform of interest rate liberalization in China. While interest rate liberalization has improved the development of China's economy and better allocated resources, it also contains a lot of risks.

\section{The influence}

\subsection{The positive influence of interest rate liberalization on China's commercial banks}

\subsubsection{Beneficial for commercial banks to absorb more idle funds}

Copyright $(C) 2020$ Mengting Jiang

doi: $10.18282 / \mathrm{ff.v} 9 \mathrm{i} 1.812$

This is an open-access article distributed under the terms of the Creative Commons Attribution Non-Commercial License

(http://creativecommons.org/licenses/by-nc/4.0/), which permits non-commercial use, distribution, and reproduction in any medium, provided the original work is properly cited. 
After the liberalization of interest rate, commercial banks can regulate and control the interest rate of deposit and loan independently, so as the major banks. In order to compete for customer resources, deposit interest rates will be properly raised in the short term. When deposit interest rates rise, more major customers and retail investors will deposit their idle funds in the bank, then the banks will absorb a large number of idle funds, and the absorption of these idle funds can enable them to better carry out all kinds of business, such as providing loans to companies in need of funds.

\subsubsection{Beneficial for commercial banks to innovate financial products}

Before the liberalization of interest rate, the commercial banks of China mainly obtain the income through the deposit and loan interest rate spread. After that, this way can no longer bring more benefits to the commercial banks, and the competition among the major banks is also intensified. In order to compete for more customers and improve the profit growth point, they are bound to develop more new business and improve their own service level in addition to the traditional lending business, for example, to provide financial advice to customers and to help listed companies sell securities.

\subsubsection{Beneficial for commercial banks to optimize their own structure and customer structure}

Under the background of liberalization reform of interest rate, the government abandons the direct control of interest rate, allowing the commercial banks to have the autonomy of interest rate pricing. At this time, commercial banks can fully consider their own income by calculating management costs, capital costs and operating costs, and then self-regulate interest rates according to the actual supply and demand of the market. This is beneficial for commercial banks to optimize their own structure. Secondly, through the comprehensive consideration of customers' credit situation and default, commercial banks properly increase the financing costs of those customers who may harm the interests of banks in the future, and appropriately reduce the financing costs of those customers who have good reputation and have prospects for development. This avoids the risks posed to banks by customers with poor reputation, but promotes long-term partnerships with high-quality customers

\subsection{The negative influence of interest rate liberalization on China's commercial banks}

\subsubsection{Impact on the credit risk of commercial banks}

Due to the full liberalization of loan interest rate in 2013, the major banks began to expand their loan business in the short term in order to pursue high profits. Because of the continuous expansion of loan business, it is difficult for banks to fully grasp all the real information and credit status of borrowers, which will lead to a decline in the quality of loans. The credit risk faced by banks also increases (credit risk refers to the possibility that the debtor is unable or unwilling to perform the debt and cause losses to creditors ${ }^{[2]}$ ). Non-performing loan ratio is the core index to measure the credit risk of loans. Table 1 collects and collates the non-performing loan ratios of banking financial institutions from 2012 to 2018. From the table, it can be seen that the non-performing loan ratio of the banking industry began to rise from 2013 to 2014, while the non-performing loan ratio rose sharply from 2014 to 2015, indicating that banks made a lot of non-performing loans during this period. In the following years, although the rate of non-performing loans has not increased significantly, or even declined, the proportion is still high, indicating that the disposal and management of non-performing loans require further development.

\begin{tabular}{|l|c|c|c|c|c|c|c|}
\hline & $\mathbf{2 0 1 2}$ & $\mathbf{2 0 1 3}$ & $\mathbf{2 0 1 4}$ & $\mathbf{2 0 1 5}$ & $\mathbf{2 0 1 6}$ & $\mathbf{2 0 1 7}$ & $\mathbf{2 0 1 8}$ \\
\hline Non-performing loan ratio & $1.6 \%$ & $1.5 \%$ & $1.6 \%$ & $1.9 \%$ & $1.91 \%$ & $1.85 \%$ & $1.83 \%$ \\
\hline
\end{tabular}

Table 1. Non-performing loans of banking financial institutions as a percentage of total loans from 2012 to 2018. (Data Source: Annual Report of China Banking and Insurance Regulatory Commission). 


\subsubsection{Impact on the traditional profit model of commercial banks}

The traditional profit of commercial banks is mainly obtained through the difference of interest rate between deposits and loans, while the People's Bank of China liberalized the upper limit floating area of commercial bank loans and deposit interest rates in 2013 and 2015, respectively, which greatly affected the way that commercial banks get returns through deposit and loan spreads. Table 2 collates the net interest income of some commercial banks in 2015 and 2016. As can be seen from Table 2, the net interest income of the major banks in China has decreased to varying degrees from 2015 to 2016, especially the decrease of the net interest income of the state-owned banks. This shows that because of the liberalization of interest rate, in order to compete for more customers, banks will moderately raise the interest rate of deposits and reduce the interest rate of loans, which will make commercial banks get less and less benefits from deposit and loan spreads and certainly affect their profits. If commercial banks do not change this profit model, the liberalization of interest rate will have a serious impact on their development.

\begin{tabular}{|c|c|c|c|}
\hline Net interest & $\mathbf{2 0 1 5}$ & $\mathbf{2 0 1 6}$ & Year-on-year decline \\
\hline Bank of China & 3286.50 & 3060.48 & $6.88 \%$ \\
\hline Agricultural Bank & 4361.40 & 3981.04 & $8.72 \%$ \\
\hline ICBC & 5078.67 & 4718.46 & $7.09 \%$ \\
\hline Construction Bank & 4577.52 & 4177.99 & $8.73 \%$ \\
\hline Bank of Communications & 1441.72 & 1348.71 & $6.45 \%$ \\
\hline China Merchants Bank & 1375.86 & 1345.95 & $2.17 \%$ \\
\hline China Everbright Bank & 664.59 & 652.88 & $1.76 \%$ \\
\hline
\end{tabular}

Table 2. Net interest income of commercial banks in 2015 and 2016 year. (Data Source: Data consolidation of annual bank statements)

\subsubsection{Impact on the traditional business model of commercial banks}

The interest income of banks can be broadly divided into four categories: the first is the payment of funds to individuals or enterprises and temporary advances on behalf of clients; the second is the income of investing funds in securities; the third is the income of depositing some of the funds in the income of monetary authorities; and the fourth is the remuneration of lending funds to other banks to help them out of trouble. The liberalization of interest rate reduces the difference between deposit and loan interest rate, and the benefits obtained by banks through this way are gradually decreasing. In addition, due to the liberalization of interest rates, the prices of stocks, bonds, futures and so on will fluctuate up and down, and it will be more difficult for banks to invest. Relatively little is paid for the deposit of funds in the income of the monetary authorities and the lending of funds to other banks. The liberalization of interest rate has an impact on the traditional business model of commercial banks. In order to cope with this impact, commercial banks can develop intermediate business and increase non-interest income. Table 3 collates the proportion of non-interest net income of some banks from 2015 to 2018. From the table, it can be seen that the proportion of non-interest net income is relatively low, while the proportion is roughly increasing year by year, indicating that the major banks are developing intermediate business. 


\begin{tabular}{|c|c|c|c|c|}
\hline & $\mathbf{2 0 1 5}$ & $\mathbf{2 0 1 6}$ & $\mathbf{2 0 1 7}$ & $\mathbf{2 0 1 8}$ \\
\hline Bank of China & $30.71 \%$ & $36.72 \%$ & $42.82 \%$ & $28.64 \%$ \\
\hline Agricultural Bank & $18.66 \%$ & $21.33 \%$ & $17.71 \%$ & $20.19 \%$ \\
\hline Construction Bank & $24.36 \%$ & $30.95 \%$ & $27.22 \%$ & $26.20 \%$ \\
\hline ICBC & $27.20 \%$ & $30.19 \%$ & $28.14 \%$ & $26.01 \%$ \\
\hline Bank of Communications & $25.62 \%$ & $30.19 \%$ & $36.29 \%$ & $38.44 \%$ \\
\hline China Merchants Bank & $31.71 \%$ & $35.82 \%$ & $34.43 \%$ & $35.47 \%$ \\
\hline
\end{tabular}

Table 3. Net non-interest income as a percentage of operating income from 2015 to 2018. (Data Source: Data consolidation of annual bank statements)

\section{Countermeasures}

\subsection{Enhance the control of credit risk}

In order to reduce the losses caused by credit risk, banks should strengthen the credit risk supervise and control, detect and deal with problems in a timely manner, and strive to prevent the deterioration of the situation before the loss occurs or take measures to reduce the loss caused by credit risk in advance. They can strengthen the control of credit risk through the following measures: perfecting the separation system of loan examination and loan, improving the level of loan decision-making; popularizing mortgage loan and pledge loan, improving the effectiveness and security of mortgage loan and pledge loan; strengthening the inspection work after loan and actively clearing up the non-performing loan ${ }^{[2]}$.

\subsection{Vigorously develop intermediate business}

The intermediary business of commercial banks mainly include payment and settlement, bank card, agency, guarantee, commitment, transaction, fund trusteeship and consulting. Among these types of intermediate business, the income of payment and settlement business is greatly reduced, and the bank card business is developing rapidly in the commercial banks of China. However, the traditional intermediary business will no longer bring more benefits to commercial banks, so they should actively explore and innovate in order to stabilize the foundation of traditional intermediate business. Learn from the successful experience of foreign commercial banks, the development of more new types of intermediate business, such as the development of investment banks, asset management and financial products, to enhance their competitive advantage under the continuous development of business varieties. At the same time, pay attention to personnel training, establish a perfect training system, in order to ensure the professional advantages of their own business. Finally, under the liberalization of interest rate, the traditional profit model of commercial banks based on net interest income is changed to the profit model of non-interest income. This is not only conducive to commercial banks to obtain more profits, but also conducive to the innovation of financial products.

\subsection{Strengthen cooperation with the Internet industry}

Now the Internet industry is greatly developed, with more and more people using online services. Banks should cooperate with Internet enterprises on a large area to cover a wide range of online and offline services through the Internet. In addition, banks can find more customers through the integration of the Internet and develop targeted services according to their needs, which will make them feel convenient and satisfied. Then they may will establish long-term business dealings with the bank.

\subsection{Improve their own service level}

With the continuous improvement of people's living standards, customers have higher and higher requirements for efficient and considerate service. In the face of this situation, commercial banks should first establish a customer-oriented service. When customers come to the bank to do business, bank personnel should provide smile 
service, carefully ask them what kind of business they want to do, then guide and help them to complete it. If they are interested in learning more about products, bank personnel should patiently advise them. Only if customers feel the enthusiasm of the bank will they be more willing to do business at the bank.

\section{References}

1. Yang Q. The influence of interest rate liberalization on China's commercial banks and its countermeasures (in Chinese). Finance Economy 2019; 500(2): 48-50. doi: CNKI:SUN:JRJJ.0.2019-02-020.

2. $\quad$ Song Q. Bank management (second edition). China Finance Publishing House; 2017.

3. Ji X. The impact of interest rate liberalization on China's commercial banks and its countermeasures (in Chinese). Finance Economy 2019; (16).

4. $\mathrm{Lu} \mathrm{J}$. The influence of interest rate liberalization on China's commercial banks and its countermeasures (in Chinese). Modern Finance 2019; (8): 27-29.

5. Chen G. Study on the profit model of China's state-owned commercial banks (in Chinese). Shanghai: Tongji University; 2006. doi: CNKI:CDMD:2.2006.047982.

6. Hao G. An empirical analysis of the profitability of commercial banks in the process of interest rate liberalization in China (in Chinese). Research on Financial and Economic Issues.

7. Li L, Zhang W, Hu H. The profit model transformation of China's modern commercial banks (in Chinese). South China Finance 2007; (6): 42-43. doi: CNKI:SUN:GDJR.0.2007-06-015.

8. Huang J. Interest rate liberalization and risk control of commercial banks (in Chinese). Economic Research Journal 2001; (1): 19-28+94. doi: CNKI:SUN:JJYJ.0.2001-01-002.

9. Gao X. The analysis about the strategy of China's commercial banks to interest rate liberalization policy (in Chinese). University of International Business and Economics; 2006.

10. Liao X. Analysis of interest rate liberalization and China's commercial bank management (in Chinese). Market Modernization Magazine 2017; (10): 162-163. 